The Transplant Imaginary 
This page intentionally left blank 


\title{
The Transplant Imaginary
}

Mechanical Hearts, Animal Parts, and Moral

Thinking in Highly Experimental Science

\author{
LESLEY A. SHARP
}

甲

UNIVERSITY OF CALIFORNIA PRESS

Berkeley Los Angeles London 
University of California Press, one of the most distinguished university presses in the United States, enriches lives around the world by advancing scholarship in the humanities, social sciences, and natural sciences. Its activities are supported by the UC Press Foundation and by philanthropic contributions from individuals and institutions. For more information, visit www .ucpress.edu.

University of California Press Berkeley and Los Angeles, California

University of California Press, Ltd. London, England

(C) 2014 by The Regents of the University of California

Library of Congress Cataloging-in-Publication Data

Sharp, Lesley Alexandra.

The transplant imaginary : mechanical hearts, animal parts, and moral thinking in highly experimental science / Lesley A. Sharp.

pages $\mathrm{cm}$

Includes bibliographical references and index. ISBN 978-O-520-27796-O (hardback)

ISBN 978-O-52O-27798-4 (paper)

1. Transplantation of organs, tissues, etc.-Social aspects-United States. 2. Ethnology-United

States. 3. Medical anthropology-United States. I. Title.

RD120.7.S492 2013

$174.2^{\prime} 97954-\mathrm{dc} 23$

2013024442

Manufactured in the United States of America
$\begin{array}{llllllllll}23 & 22 & 21 & 20 & 19 & 18 & 17 & 16 & 15 & 14\end{array}$
$\begin{array}{llllllllll}10 & 9 & 8 & 7 & 6 & 5 & 4 & 3 & 2 & 1\end{array}$

In keeping with a commitment to support environmentally responsible and sustainable printing practices, UC Press has printed this book on Natures Natural, a fiber that contains 30\% post-consumer waste and meets the minimum requirements of ANSI/NISO Z39.48-1992 (R 1997) (Permanence of Paper). 
For my father

Rodman Alton Sharp

D.O.D.

$1930-2013$

A man who found beauty both in nature and in the tinkerer's art 
This page intentionally left blank 